\title{
A Highly Sensitive Adenylate Cyclase Assay
}

\author{
YORAM SALOMON, CONSTANTINE LONDOS, \\ AND MARTIN RODBELL
}

\begin{abstract}
Section on Membrane Regulation, Laboratory of Nutrition and Endocrinology, National Institute of Arthritis, Metabolism, and Digestive Diseases, National Institutes of Health, Bethesda, Maryland 20014
\end{abstract}

Received August 8, 1973; accepted October 3, 1973

\begin{abstract}
A highly sensitive adenylate cyclase assay method has been developed which employs sequential chromatography on columns of Dowex cation exchange resin and aluminum oxide. With the use of $\left[\alpha{ }^{32} \mathrm{P}\right] \mathrm{ATP}$ as substrate, this method permits the nearly complete separation of cyclic $\left[{ }^{32} \mathrm{P}\right] \mathrm{AMP}$ formed from the substrate and other ${ }^{32} \mathrm{P}$-containing compounds, i.e., ${ }^{32} \mathrm{P}$ in the assay blanks was barely detectable. In comparative studies, this method was found to be considerably more sensitive than previously reported methods. The high sensitivity of this method permits detection of the small amounts of cyclic AMP formed at low enzyme concentrations or at early time points in kinetic studies.
\end{abstract}

Adenylate cyclase, the enzyme that catalyzes the formation of cyclic adenosine $3^{\prime}, 5^{\prime}$-monophosphate (cyclic AMP) from ATP, may be assayed in vitro by measuring the production of radioactively labeled cyclic AMP from the substrate $\left[\alpha^{-3} \mathrm{P}\right] \mathrm{ATP}$. A particular problem in assaying this enzyme results from the fact that only a minute fraction, usually less than $0.05 \%$, of the substrate is converted to cyclic AMP. Assay sensitivity is largely dependent upon and proportional to the efficiency with which cyclic AMP is separated from the labeled substrate and radioactive contaminants. In other words, at any given level of specific radioactivity of substrate, sensitivity approaches a maximum as the radioactivity (cpm ${ }^{32} \mathrm{P}$ ) in the assay blanks approaches zero.

Two methods are widely used for the isolation of radioactive cyclic AMP formed in in vitro assays. Krishna et al. (1) have shown that the bulk of the ATP may be separated from cyclic AMP by chromatography on Dowex cation exchange resin. The column eluate is subsequently treated with nascent $\mathrm{BaSO}_{4}$ which removes most of the remaining ATP and other labeled contaminating materials. More recently, White and Zenser (2) and Ramanchandran (3) have shown that separation of cyclic AMP from ATP may be accomplished in a one-step procedure by employing chromatography over aluminum oxide. While both methods enable a single 
investigator to process a large number of samples with relative ease, neither results in the complete elimination of ${ }^{32} \mathrm{P}$ in the assay blanks.

We here report a highly sensitive assay method for adenylate cyclase, based on a combination of chromatography on both Dowex cation exchange resin and aluminum oxide, which permits the nearly complete elimination of radioactivity in the assay blanks.

\section{MATERIALS}

$\left[\alpha^{32} \mathrm{P}\right] \mathrm{ATP}$ and cyclic AMP were obtained from International Chemical and Nuclear Corp. and cyclic $\left[{ }^{3} \mathrm{H}\right] \mathrm{AMP}$ and Aquasol scintillation cocktail from New England Nuclear Corp. Glucagon was purchased from Eli Lilly and Co. Dowex AG50 WX4 cation exchange resin (200-400 mesh, $\left.\mathrm{H}^{+}\right)$was from Bio-Rad. Neutral Chromatographic Alumina WN-3, creatine phosphate, and creatine phosphokinase were from Sigma.

\section{ME'THODS}

Preparation of hepatic plasma membranes. Partially purified plasma membranes from rat livers were prepared by a modification (4) of the procedure of Neville (5) and stored in liquid nitrogen.

Protein determination. Protein was determined according to Lowry et al. (6) with the use of bovine serum albumin as standard.

Adenylate cyclase assay. The incubation mixture contained $25 \mathrm{~mm}$ Tris-HCl, $\mathrm{pH} 7.5,5 \mathrm{~mm} \mathrm{MgCl}_{2}, 20 \mathrm{~mm}$ creatine phosphate, $100 \mathrm{U} / \mathrm{ml}$ creatine phosphokinase, $1 \mathrm{~mm}$ cyclic AMP, $1 \mathrm{~mm}\left[\alpha^{-32} \mathrm{P}\right] \mathrm{ATP} \quad(40-50$ $\mathrm{cpm} / \mathrm{pmole}$ ), and glucagon or sodium fluoride as indicated. The reaction was initiated by the addition of membranes to give $10-250 \mu \mathrm{g} / \mathrm{ml}$ of membrane protein in a final reaction volume of $100 \mu \mathrm{l}$. Temperature was $30^{\circ} \mathrm{C}$, and, unless otherwise indicated, incubation time was $5 \mathrm{~min}$. The reaction was stopped by the addition of $100 \mu l$ of "stopping solution" containing $2 \%$ sodium dodecylsulfate, $40 \mathrm{~mm}$ ATP, and $1.4 \mathrm{~mm}$ cyclic AMP at $\mathrm{pH}$ 7.5. Cyclic $\left[{ }^{3} \mathrm{H}\right]$ AMP (approximately $20,000 \mathrm{cpm}$ ) in $50 \mu \mathrm{l}$ was then added to monitor cyclic AMP recovery.

For kinetic studies, the assay reagents were as described above, but the reaction volume was $1.0 \mathrm{ml}$. Aliquots of $100 \mu \mathrm{l}$ were withdrawn at the indicated times and transferred into test tubes containing $100 \mu \mathrm{l}$ of stopping solution; cyclic $\left[{ }^{3} \mathrm{H}\right]$ AMP was then added as described above.

Assay blanks were prepared by omitting membranes or by adding membranes after the stopping solution; both methods gave equivalent blank values.

Isolation of cyclic AMP. Reaction tubes containing $250 \mu \mathrm{l}$ (100 $\mu \mathrm{l}$ incubation mixture $+100 \mu$ l stopping solution $+50 \mu$ cyclic $\left[{ }^{3} \mathrm{H}\right]$ AMP solution) were processed according to Method A, B, or C. 
Method A (According to White and Zenser (2)). To each reaction tube was added $0.75 \mathrm{ml} 50 \mathrm{~mm}$ Tris- $\mathrm{HCl}, \mathrm{pH} 7.5$; the tubes were mixed and decanted into columns $(0.4 \times 15 \mathrm{~cm})$ containing $1 \mathrm{~g}$ neutral alumina (previously equilibrated with the same buffer), and the eluate discarded. Two $\mathrm{ml}$ of the Tris buffer were added to each column and the eluate collected directly into scintillation vials containing $12 \mathrm{ml}$ Aquasol.

Method $B$ (According to Krishna et al. (1) with modifications described by Rodbell (7). A further modification, found to improve cyclic AMP recovery, was the substitution of Dowex 50AG WX4 resin for the Dowex 50AG WX8 resin (8)).

After addition of $0.8 \mathrm{ml} \mathrm{H}_{2} \mathrm{O}$ to each reaction tube, the tubes were mixed and decanted into columns $(0.4 \times 15 \mathrm{~cm})$ containing $1 \mathrm{ml}$ Dowex resin. The eluate from this and two suecessive $1-\mathrm{ml} \mathrm{H}_{2} \mathrm{O}$ washes were discarded. Three milliliters of $\mathrm{H}_{2} \mathrm{O}$ were then added to each column and the eluate collecter in $13 \times 100 \mathrm{~mm}$ test tubes. (Note: this $3-\mathrm{ml}$ fraction serves as the starting point for the description of Method $\mathrm{C}$ below.) The solution was treated with $0.2 \mathrm{ml} 0.15 \mathrm{M} \mathrm{ZnSO}_{4}$ followed by $0.2 \mathrm{ml} 0.15 \mathrm{M} \mathrm{Ba}(\mathrm{OH})_{2}$, and, after rapid mixing, the suspension was decanted into columns $(0.4 \times$ $15 \mathrm{~cm}$ ) containing a plug of $\mathrm{BaSO}_{4}$ precipitate. The eluate was collected directly into scintillation vials containing $12 \mathrm{ml}$ Aquasol.

Method $C$. This procedure is identical to Method B above through the $3-\mathrm{ml}$ fraction collected from the Dowex columns. To each 3 -ml fraction, $0.2 \mathrm{ml}$ of $1.5 \mathrm{M}$ imidazole- $\mathrm{HCl}, \mathrm{pH} 7.2$, was added; upon dilution, the $\mathrm{pH}$ rises to approximately 7.5 . The tubes were mixed and decanted into columns $(0.4 \times 15 \mathrm{~cm})$ containing $0.6 \mathrm{~g}$ neutral alumina that had been washed previously with $8 \mathrm{ml}$ of $0.1 \mathrm{M}$ imidazole- $\mathrm{HCl}, \mathrm{pH}$ 7.5. The eluate was collected directly into scintillation vials containing $12 \mathrm{ml}$ Aquasol. After the columns were completely drained, an additional $1 \mathrm{ml}$ of the $0.1 \mathrm{~m}$ imidazole- $\mathrm{HCl}, \mathrm{pH} 7.5$, buffer was added and collected in the scintillation vials.

Recycling of Dowex columns. At the completion of each experiment, $2 \mathrm{ml}$ of $1 \mathrm{~N} \mathrm{HCl}$ were added to each Dowex column and the columns stored with no further treatment. Prior to reusing, the columns were washed with $10 \mathrm{ml} \mathrm{H}_{2} \mathrm{O}$.

Reuse of alumina columns. Prior to experiments conducted according to Method C, the alumina columns were washed with $8 \mathrm{ml} 0.1 \mathrm{~m}$ imidazole$\mathrm{HCl}, \mathrm{pH} 7.5$.

\section{RESULTS}

Table 1 shows the results of an experiment in which basal, glucagonand fluoride-stimulated activities of hepatic adenylate cyclase were determined by Methods A, B, and C. Good agreement was obtained with all 


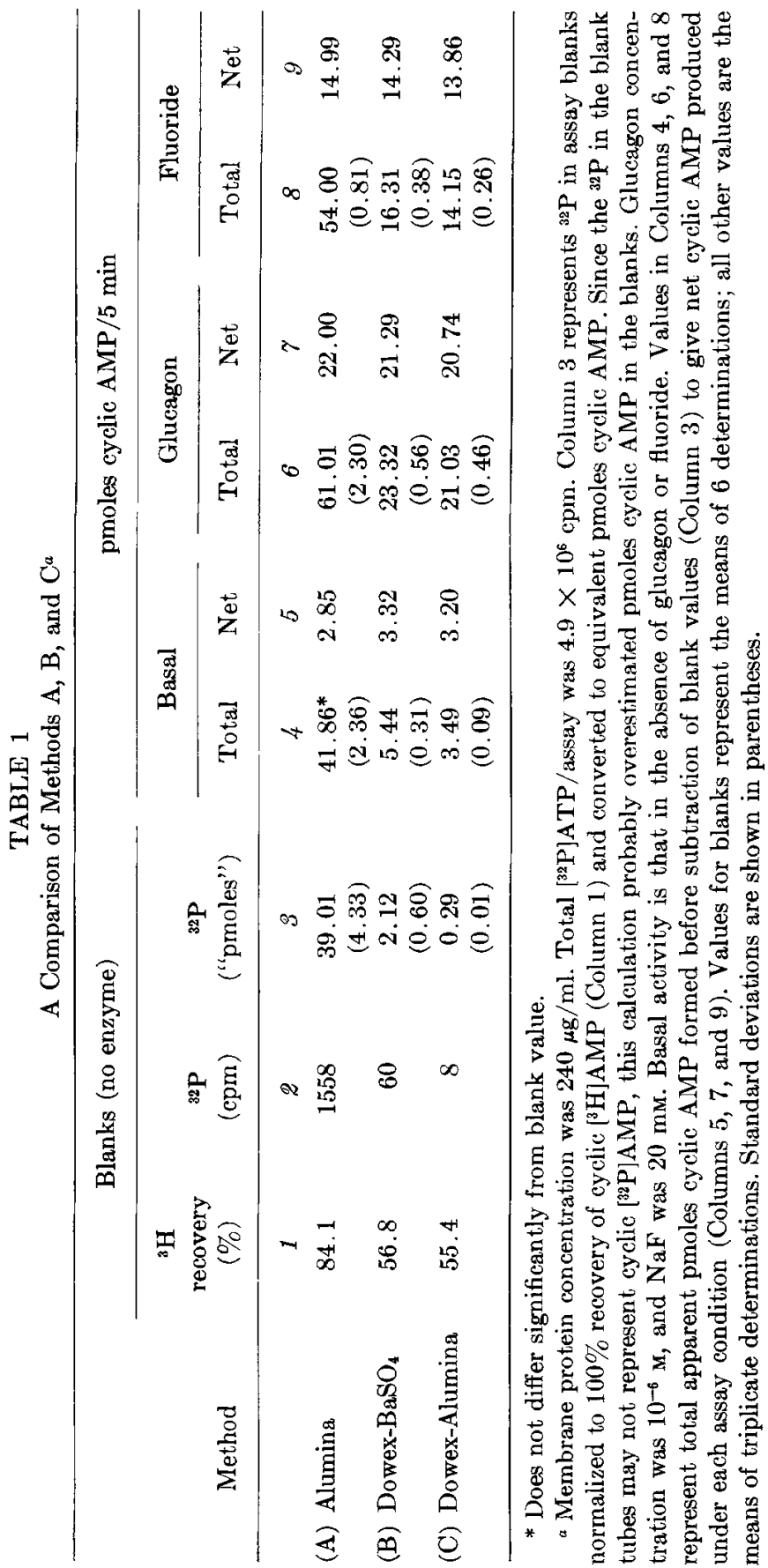


three methods for the glucagon- and fluoride-stimulated activities. Basal activity was comparable with Methods $\mathrm{B}$ (Dowex-BaSO${ }_{4}$ ) and $\mathrm{C}$ (Dowex-alumina), while with Method A (alumina only) basal activity did not differ significantly from the reaction blank value.

Reaction blank levels and cyclic AMP recoveries are also listed in Tablc 1. While Mcthod A gave the highest cyclic AMP recovery, it also resulted in the highest blank value, $1558 \mathrm{cpm}$ or $0.03 \%$ of the total ${ }^{32} \mathrm{P}$ in the reaction mixture. In several experiments conducted according to Method A, blank values were found to range from 0.01 to $0.03 \%$ of total ${ }^{32} \mathrm{P}$. Method $\mathrm{B}$ gave a lower value, $60 \mathrm{cpm}$ or $0.0015 \%$. Method $\mathrm{C}$ gave the lowest blank value, only $8 \mathrm{cpm}{ }^{32} \mathrm{P}(0.0002 \%)$, which barely differed from machine counting background. Recoveries of cyclic [ $\left.{ }^{3} \mathrm{II}\right] \mathrm{AMP}$ were equivalent for Methods $\mathrm{B}$ and $\mathrm{C}$, approximately $55 \%$, and the loss of cyclic AMP occurred primarily on the Dowex columns; neither $\mathrm{BaSO}_{4}$ nor alumina treatment were found to remove significant amounts of cyclic AMP.

The relative sensitivities of the three methods are illustrated in Fig. 1, which shows basal and glucagon-stimulated activities as a function of enzyme concentration over the range of $15-240 \mu \mathrm{g}$ membrane protein $/ \mathrm{ml}$. With Method C, basal and hormone-stimulated activities were easily measured over the entire enzyme concentration range, while with Method $B$ basal activities were never more than twice the blank values. With Method A, basal activity did not differ from the blank values over the

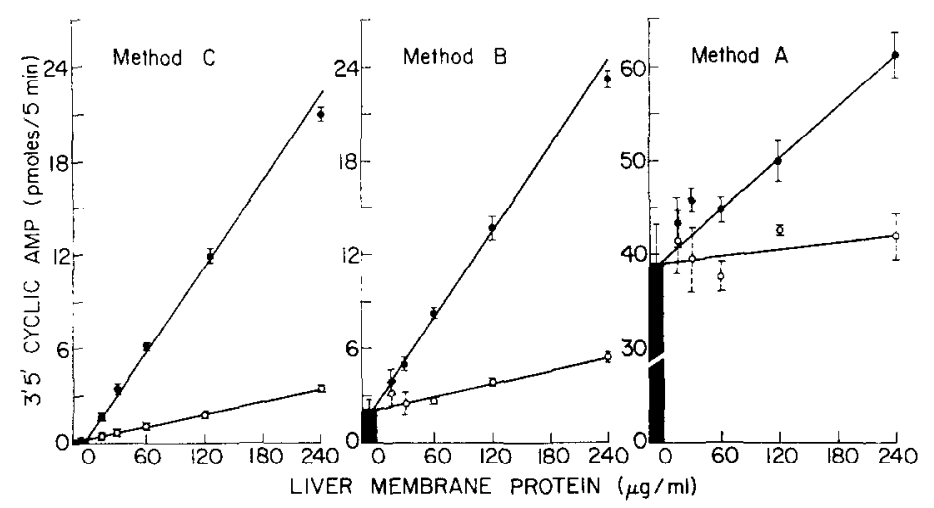

FIg. 1. Adenylate cyclase activity as a function of liver membrane protein: $A$ comparison of Methods A, B, and C. Total [ ${ }^{32} \mathrm{P}$ ]ATP/assay was $4.9 \times 10^{6} \mathrm{cpm}$. Basal activity is indicated by open circles, activity with glucagon by solid circles. Vertical bars represent the means of 6 background determinations; these values have been converted to equivalent pmoles cyclic AMP as described in the legend to Table 1. All other points represent triplicate determinations. Vertical lines represent standard deviations. Note different scales on ordinate axes. 
entire enzyme concentration range, and hormone-stimulated activity could only be measured at the higher protein concentrations tested.

Recent studies in this laboratory on the glucagon-sensitive adenylate cyclase system have shown the value of short-term kinetic studies in evaluating the mechanism of hormone action (9). An example of such an experiment is depicted in Fig. 2. Note that basal activity proceeded without a lag from time zero. However, at submaximal glucagon concentrations, the onset of hormone-stimulated activity occurred only after a lag; this lag was decreased by increasing the hormone concentration. As will be described elsewhere, conditions may be varied to show lags of up to $3 \mathrm{~min}(9)$. Kinetic studies should be greatly facilitated by Method C which permits the measurement of basal activity at early time points.

White and Zenser (2) have shown that with the alumina method (Method A), careful attention to buffer $\mathrm{pH}$ and concentration are essential to minimize the blank values. With our method (Method C), in which the assay mixture is passed through the Dowex resin before chromatog-

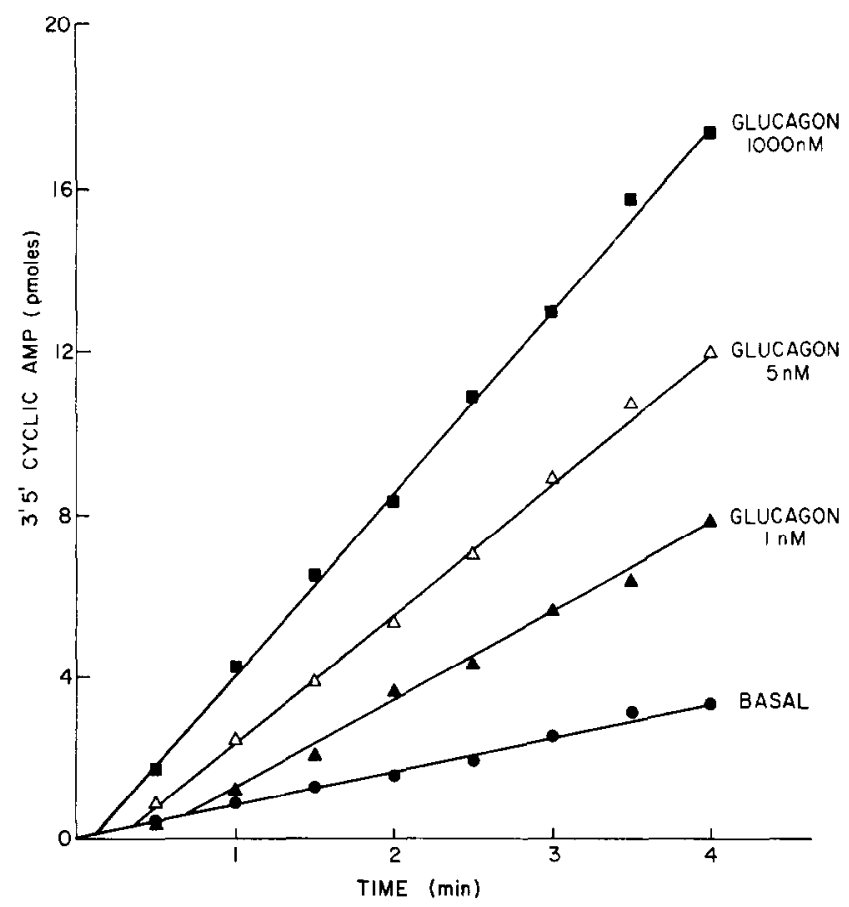

FIg. 2. Time course of basal and glucagon-stimulated adenylate cyclase activity. Membrane protein concentration was $210 \mu \mathrm{g} / \mathrm{ml}$. Total [ $\left.{ }^{32} \mathrm{P}\right]$ ATP/assay was $4.2 \times 10^{n}$ cpm. Samples were processed according to Method C. Values represent the means of duplicate determinations. 
raphy on alumina, these factors are not so critical. We have tested $100 \mathrm{~mm}$ imidazole- $\mathrm{HCl}$ over the $\mathrm{pH}$ range of $6.3-7.9$ and $20-200 \mathrm{~mm}$ imidazole$\mathrm{HCl}$ at $\mathrm{pH} 7.5$ and found essentially equivalent results under all of these conditions. It should be noted that in Method C, 99\% of the ${ }^{32} \mathrm{P}$ is removed by chromatography over the Dowex resin prior to passage over alumina, whereas in Method A the total ${ }^{32} \mathrm{P}$ is applied to the alumina column. Therefore, small variations in blank values resulting from the buffer composition would not be as noticeable in Method $\mathrm{C}$ as in Method A.

In the past, we prepared fresh Dowex columns for each experiment, which proved to be an expensive and time-consuming endeavor. The experiments reported here were conducted with the use of recycled Dowex columns that had been used at least 30 times. Moreover, we have reused the alumina columns in at least 10 experiments conducted according to Method $\mathrm{C}$ and have found no significant increases in the blank values. The upper limit for the number of times either type of column may be reused has not been determined.

\section{DISCUSSION}

Assay sensitivity, under the criteria applied to these studies, varies inversely with the level of ${ }^{32} \mathrm{P}$ in the assay blanks. Sensitivity is greatest with the use of assay Method C (Dowex-alumina), which we have found to be 7-20 times more sensitive than Method B (Dowex-BaSO ${ }_{1}$ ) and far more sensitive than Method A (alumina only). Therefore, Method C is clearly preferable where high sensitivity is desired.

Method $\mathrm{C}$ provides a further advantage in that it requires less effort than do the other two methods described. The most time-consuming aspect of these techniques is the preparation of the columns. Although Method A requires only alumina columns, these columns retain nearly all of the ${ }^{32} \mathrm{P}$ in the assay mixture. Reuse of these columns may, therefore, expose the investigator to undesirable levels of radioactivity. This is not a problem with the alumina columns from Method C, since approximately $99 \%$ of the ${ }^{32} \mathrm{P}$ is already removed by passage through the column of Dowex resin. With Method $\mathrm{B}$, fresh $\mathrm{BaSO}_{4}$-plugged columns are required for each experiment, since the accumulation of $\mathrm{BaSO}_{4}$ precipitate would clog the columns. Method $\mathrm{C}$ permits reuse of the columns with corresponding reduction in time and effort.

The high sensitivity of Method $\mathrm{C}$ should, in the interests of safety and economy, permit the lowering of radioactivity required in the adenylate cyclase assay. Moreover, the higher sensitivity of this method allows the use of lower concentrations of membrane protein in the assay; this aspect 
is of obvious benefit when yields of purified membrane are low, as is frequently the case.

Note added in proof: Since this manuscript was submitted a modification of Method $\mathrm{C}$ was developed for routine use when very high sensitivity is not necessary. Rather than collect the $3 \mathrm{ml}$ eiuate of the Dowex column in a test tube, this fraction is passed directly into the alumina column, and the subsequent eluate discarded. Four ml $0.1 \mathrm{~m}$ imidazole$\mathrm{HCl}, \mathrm{pH} \mathrm{7.5}$, are added to the alumina column and the eluate collected directly in scintillation vials. With this modification assay blank valucs range from 3 to $5 \mathrm{cpm}{ }^{32} \mathrm{P}$ per million $\mathrm{cpm}$ in the assay mix.

\section{ACKNOWLEDGMENTS}

We are most grateful to Drs. James P. Harwood and Michael C. Lin for their valuable advice in the preparation of this manuscript.

This investigation was supported in part by a National Institutes of Health Fellowship (4 FO3 DE51657-03) from the National Institute of Dental Research.

\section{REFERENCES}

1. Krishna, G., Weiss, B., and Bropie, B. B. (1968) J. Pharmacol. Exp. Ther. 163, 379.

2. White, A. A., ANd Zenser, T. V. (1971) Anal. Biochem. 41, 372.

3. Ramanchandran, J. (1971) Anal. Biochem. 43, 227.

4. Pohl, S. L., Birnbaumer, L., and Rodbell, M. (1971) J. Biol. Chem. 246, 1849.

5. Neville, D. R. (1968) Biochim. Biophys. Acta 154, 540.

6. Lowry, O. H., Rosebrough, N. Y., Farr, A. L., and Randall, R. J. (1951) J. Biol. Chem. 193, 265.

7. Rodbelu, M. (1972) in Methods in Molecular Biology (M. Chasin, ed.), Vol. 3, p. 101, Marcel Dekker, Inc., New York.

8. Harwood, J. P. (1973) personal communication.

9. Robbell, M., Lin, M. C., and Salomon, Y. (1974) J. Biol. Chem. 249, 59. 